Statistics project of the National Institute of Economic and Social Research. The following have been appointed lecturers in the University : J. Preston (geology, with special reference to petrology); Dr. R. Henstock (mathematics); R. A. D. Egerton and J. S. Fforde (economics).

\section{University of Birmingham}

Dr. A. E. Duncan-Jones has been appointed to succeed Prof. L. J. Russell as professor of philosophy in the University of Birmingham; Dr. Duncan-Jones is at present lecturer in the University. The following have been appointed lecturers in the subjects indicated : J. R. Gibson (zoology), K. Butler (chemistry), A. P. Garrett (geology). The following have resigned from the University: Dr. R. L. Whitmore, lecturer in coal treatment, on appointment as head of the Mechanical Sciences Department, Ferodo, Ltd.; G. L. Hatherley, lecturer in metal mining, on appointment to the Rhokana Corporation, Ltd., Northern Rhodesia.

\section{University of London: Appointments}

THe following appointments in the University of London have been made: Dr. M. J. S. Dewar, to the University chair of chemistry tenable at Queen Mary College from October 1; Dr. Christoph von Fürer-Haimendorf, to the University chair of Asian anthropology tenable at the School of Oriental and African Studies from October 1; Dr. Harry Butler, to the University readership in anatomy tenable at St. Bartholomew's Hospital Medical College from October I.

Royal Society of South Africa: Officers for 1951

THE following have been elected to the Council for 1951 of the Royal Society of South Africa: President, Prof. R. W. James ; Honorary Secretary, Prof. W. J. Talbot; Honorary Treasurer, N. Sapeika; Acting Editor of Transactions, A. M. Talbot; Honorary Librarian, Prof. E. Newbery; Other Members of Council, Prof. J. H. O. Day, Prof. W. E. Isaac, Prof. W. Pugh, Prof. D. L. Scholtz, S. H. Skaife, Prof. J. L. B. Smith, Prof. C. J. v. d. Horst, Prof. F. Walker and C. L. Wicht.

\section{Colonial Service: Recent Appointments}

THE following appointments in the Colonial Service have recently been announced: D. H. Brown (assistant director of agriculture, Nigeria), regional deputy director of agriculture (supernumerary), Nigeria; H. W. Dougall (agricultural chemist, Sierra Leone) and J. L. Greig (State agricultural officer, Sierra Leone), pasture research chemists, Agricultural Department, Kenya; E. Williams (agricultural officer, Uganda), assistant director of agriculture, Nyasaland; E. G. N. Greaves (deputy government chemist, Trinidad), government chemist, Trinidad; A. E. Kerr (assistant government chemist, Trinidad), deputy government chemist, Trinidad; E. J. Shrubshall (conservator of forests, Federation of Malaya), deputy director of forestry, Federation of Malaya; M. L. Webber (senior assistant conservator of forests, Federation of Malaya), conservator of forests, Federation of Malaya; D. A. Bates (deputy director of the Geological Survey, Gold Coast), director of the Geological Survey, Gold Coast; W. H. Reeve (engineer geologist, Kenya), chief geologist, Northern Rhodesia; D. A. Fletcher (senior forester, Tanganyika), superintending forester, Tanganyika; A. D. Mercer (weed control officer, Fiji), agricultural officer,
Fiji ; R. B. Silcock (agricultural assistant, Tanganyika), superintendent of agriculture, Tanganyika; H. M. Thompson (senior laboratory assistant, Jamaica), agricultural chemist. Jamaica; A. E. Weirich (agricultural assistant, Tanganyika), superintendent of agriculture, Tanganyika; D. P. Allan, agricultural officer, Tanganyika; H. Bailey, agricultural officer, Gambia; Miss M. M. Sheahan, veterinary research officer, Nigeria; R. W. Crosskey, entomologist, Nigeria; V. T. Hinds, fisheries officer, Somaliland Protectorate; R. J. Streets, assistant conservator of forests, Cyprus.

\section{"Classification of the Coli-Aerogenes Bacteria"}

A REPORT on the classification of the coli-aerogenes bacteria is mentioned in Nature of May 19, p. 799. Copies of this report can be obtained from the treasurer of the Society for Applied Bacteriology, T. E. Bashford, The Metal Box Co., Ltd., Kendal Avenue, Westfields Road, Acton, London, W.3, and not from the general secretary of the Society for General Microbiology as stated.

\section{Announcements}

Dr. L. E. CAMPBell, director of research of the British Food Manufacturing Industries Research Association, has been appointed food technologist to the United Nations Food and Agriculture Organization, Rome. Dr. F. H. Benfield, deputy director of the Research Association since 1948, has been appointed director.

DR. K. R. Atkins, of the Royal Society Mond Laboratory, Cambridge, has been appointed associate professor of physics in the University of Toronto and will take up his duties in September.

THE following appointments have recently been made in the Department of Physical Metallurgy, University of Sheffield : Dr. R. W. K. Honeycombe to be senior lecturer; Dr. G. B. Greenough and Dr. D. W. Wakeman to be lecturers.

Four postdoctorate fellowships, for the study of trace elements in the soil, tenable at the McCollumPratt Institute, Johns Hopkins University, have been awarded to the following for study as indicated: E. J. Johnson Fellowship, Dr. D. J. D. Nicholas, plant physiologist, of the Plant Nutrition Institute, University of Bristol (trace-element deficiency and the enzyme construction of plants); C.F. Kettering Fellowship, Dr. Ronald Moss, plant physiologist, of Iowa State College (trace-element deficiency and amino-acid metabolism); McCollum-Pratt Fellowships, Dr. Lazarus Astrachan, physiological chemist, of Yale University, and Dr. Leonard J. Zatman, biochemist, of the Research Institute of Montreal General Hospital, Canada (phosphorus as a trace element).

The Société Française de Métallurgie will hold its annual "Journées métallurgiques d'Automne" in Paris during October 22-27. The meeting will be run on similar lines to that arranged last October, when a large number of specialists from other eountries presented papers. Those interested are invited to write to the Société Française de Métallurgie, 5 Cité Pigalle, Paris $9 \mathrm{e}$.

Messrs. Chapman and Hall, Ltd., are sole agents in the British Empire for the Thomas William Salmon Memorial Lectures. One of these Lectures, "Cell Growth and Cell Function", by Prof. T. O. Caspersson, was reviewed in Nature of May 12; the English price is $28 s$. net. 